\title{
The Rise of Indigenous Military History
}

The role of war in shaping nations' identities is unparalleled. In the United States, the Second World War and the idea of 'The Greatest Generation' epitomise the mythology of American values of service, courage and patriotism. ${ }^{1}$ In Australia, and to a lesser extent New Zealand, the First World War Anzac mythology of the brave soldier, fighting against overwhelming odds, and forming the bonds of mateship has become sacrosanct. Canada's victory in the First World War Battle of Vimy Ridge is regularly touted as the birthplace of the modern nation. South Africa’s Afrikaaner community especially looks to Second Anglo-Boer War as a key moment shaping the nation's destiny.

While some historians continuously question the mythology surrounding these and other war histories, ${ }^{2}$ other historians have sought to produce more inclusive military histories. Such historians focus on the voices of the forgotten, such as women, immigrants, the working class or racial and ethnic minorities. Among these new social military histories of twentiethcentury conflicts, literature on Indigenous participation has been prominent. Indigenous peoples fought in Euro-American conflicts in various capacities, ranging from integrated soldiers in normal units, to segregated labour forces, to specialist Indigenous units. The rise of Indigenous military histories has been a global postcolonial phenomenon, though this article focuses on the major Anglo-settler societies: Australia, Canada, New Zealand, South Africa and the United States.

This article traces the historiography of Indigenous military histories from the few pre-1980s studies which focused on specific tribes, through the rise of national Indigenous military histories in the 1980s and 1990s, to the current focus on comparative, transnational and colonial dimensions. The first national histories tended to emphasise Indigenous contributions as positive stories, though they still acknowledged discriminatory government

\footnotetext{
${ }^{1}$ Brokaw, The Greatest Generation.

${ }^{2}$ See, for example, Lake and Reynolds, What's Wrong with Anzac?; Scates, et. al, 'Anzac Day at Home and Abroad', 523-536; Hayes, Iarocci and Bechtold (eds), Vimy Ridge.
} 
policies. Such histories reflected the sentiments of reconciliation that were on the national agendas in the 1990s and represented positive stories which (unintentionally) contrasted with more negative histories of frontier conflict and assimilation policies. More recent histories have sought nuanced approaches, looking at the valiant efforts of Indigenous service personnel and their diverse motivations to serve, in conjunction with the often exploitative government approaches to Indigenous recruitment. The new transnational and comparative histories emphasise common patterns and contextualise military service within the global context of settler colonialism.

\section{Early Tribal Histories}

Before the 1970s, few academics were writing Indigenous histories. There were some notable exceptions, especially in New Zealand. Māori political and social status within New Zealand was comparatively better than that of Indigenous people in other Anglo-settler societies. ${ }^{3}$ They are also a larger percentage of the population than in other cases. Thus they were not so marginalised from national historical narratives. The first text to consider Māori in the First World War came as early as 1926, tracing the history of Māori participation, which was almost entirely in the Māori Pioneer Battalion. James Cowan examined their brave roles at Gallipoli, on the Western Front and homefront debates about Māori conscription. ${ }^{4}$

Notwithstanding its year of publication, Cowan's monograph continues to be a defining history of Māori in the First World War. P.S. O’Connor's thirty-five page article in 1967 used primary sources to present a detailed narrative of the homefront politics of Māori participation, especially the debates and eventual decision to extend conscription to Māori. ${ }^{5}$ To date there has only been one other monograph examining Māori in the First World War: Chris Pugsley's Te Hokowhitu a Tu (1995). Pugsley's book mixes narrative, primary

\footnotetext{
${ }^{3}$ See Evans et al. Equal Subjects, Unequal Rights.

${ }^{4}$ Cowan, The Maoris in the Great War.

${ }^{5}$ O’Connor, 'The Recruitment of Maori Soldiers, 1914-18', 48-83.
} 
documents and photographs to retell the story of Māori in the First World War. ${ }^{6}$ The source base and narrative do not differ extensively from Cowan or O’Connor, demonstrating the value of these earlier works.

Also receiving limited scholarly attention before the 1980s were Native Americans in the United States. In the 1940s, anthropologists John Adair and Evon Vogt conducted fieldwork interviewing Navajo and Zuni Second World War veterans. Reflecting the assimilationist discourse of the time, Adair and Vogt argued that military service exposed Navajos and Zunis to white culture and catalysed a process of assimilation. ${ }^{7}$ The pattern of tribal-focused studies continued in the 1970s when Doris Paul wrote the first monograph (1973) about the now-renowned Navajo Code Talkers. Using a mix of military documents and oral history interviews with Navajo veterans, Paul documented how the Marine Corps recruited 420 Navajo men to use their language as an unbreakable code in the Pacific War. ${ }^{8}$

The Navajo Nation also published its own collection of Second World War veterans' testimonies in 1977. The collection canvasses diverse experiences including of regular soldiers and Code Talkers, of Reservation life during the war, of those who relocated to cities and even of Navajo servicewomen. ${ }^{9}$ It was not until the 1990s that the Navajo Code Talkers came to prominence in the United States national war narrative. This decade witnessed a proliferation of popular histories about the Navajo Code Talkers, ${ }^{10}$ culminating in the 2002 film Windtalkers. The incorporation of the Navajo Code Talkers within United States Second World War mythology came about through the strong lobbying of the Navajo Code Talkers' Association, historians and other Native and non-Indigenous allies. As I have argued elsewhere, while of course the valiant work of these servicemen deserves recognition, the appropriation of the Code Talker narrative isolates the Native American Second World War

\footnotetext{
${ }^{6}$ Pugsley, Te Hokowhitu a Tu.

${ }^{7}$ Vogt, Navaho Veteran; Adair and Vogt, 'Navaho and Zuni Veterans', 547-561.

${ }^{8}$ Paul, The Navajo Code Talkers.

${ }^{9}$ Johnson (ed.), Navajos and World War II.

${ }^{10}$ Bixler, Winds of Freedom; Durrett, Unsung Heroes of World War II; McClain, Navajo Weapon.
} 
experience from their wider history of oppression. The United States government can regularly honour Code Talkers while simultaneously remaining silent about histories of enduring hardship among veterans and other Native American communities. ${ }^{11}$

\section{The Rise of National Histories}

In the 1980s, as the Black Power and Red Power movements of the 1970s waned (except in South Africa), academic historians across the settler societies began to write histories of settler-Indigenous relations. Most attention was on frontier wars, Indigenous resistance and stories that (re)positioned Indigenous people as 'good guys' fighting against everencroaching colonial powers. Such histories supported Indigenous people’s claims for land rights and made visible the underlying historical reasons for their continuing disadvantage.

This period also witnessed the beginnings of Indigenous military history, though historians' interest in frontier wars meant that publications on twentieth-century conflicts were scant. The first South African study, Kenneth Grundy's Soldiers Without Politics (1983), examined Black, Coloured and Indian military service in the twentieth century, but with focus on the Second World War and during the apartheid era. Grundy argues that Black soldiers signed up primarily for economic reasons rather than to argue for equal rights. Moreover, as there was an oversupply of available non-white recruits, any argument to reform racial policies as recognition for defence contributions had little impact. ${ }^{12}$ Even today Grundy's book is the only monograph addressing Black South African military service in the apartheid era.

Black South Africans in the First World War also received some scholarly attention in the 1980s. Albert Grundlingh's Fighting Their Own War (1987) examines both the political dimensions of Black military service, as well as the actual experiences of Black soldiers. The

\footnotetext{
${ }^{11}$ Riseman, Defending Whose Country?, 214-219

${ }^{12}$ Grundy, Soldiers Without Politics.
} 
government relegated Black servicemen to the South African Native Labour Contingent (SANLC), formed in September 1916 and employed in France primarily for loading and unloading ships as well as to maintain infrastructure. Grundlingh argues that the 21,000-manstrong SANLC did not produce greater civil rights for Blacks. His examination of the homefront also concludes that urbanisation and industrialisation during the war catalysed a process of proletariatisation. In a similar way to Grundy’s argument, Grundlingh deems the SANLC members to have been motivated primarily by economic necessity rather than political activism. ${ }^{13}$ Norman Clothier’s Black Valour (1987) also reconstructs the narrative of the SANLC, but focused on the loss of more than 600 members in the sinking of the vessel Mendi in the English Channel in $1917 .{ }^{14}$

The works of Grundy, Grundlingh and Clothier are still the only scholarly monographs focused specifically on post-Anglo Boer War (1899-1902) Black South African military history. Grundlingh argues that the First and Second World Wars have generally been on the periphery of South African historiography, which concentrates on domestic wars (for instance the Anglo-Boer War). If the world wars are mostly absent from South African historiography, then the role of Black South Africans is even further marginalised. ${ }^{15}$ Perhaps another reason that there has been little research (and this is merely speculation) is a sentiment that Black soldiers, who as Grundy and Grundlingh argue were not advocating for equal rights, were collaborators with the apartheid regimes. Such a history does not fit well with post-apartheid South Africa’s national narrative of Black resistance to oppression.

National studies of Indigenous service also emerged in Australia at the same time that Aboriginal activists were agitating for national land rights, a treaty and protesting the Bicentenary celebrations of 1988. David Huggonson identified evolving government policies towards Aboriginal enlistment in the First World War, as well as the generally egalitarian

\footnotetext{
${ }^{13}$ Grundlingh, Fighting Their Own War.

${ }^{14}$ Clothier, Black Valour.

${ }^{15}$ Grundlingh, 'The King’s Afrikaners?' 351.
} 
experiences of what was then estimated to be $400-500$ Aboriginal soldiers (now that estimate is up to 1,000$) \cdot{ }^{16}$ Most significant, though, was the work of Robert Hall, whose monograph The Black Diggers (1989) is still the most comprehensive history of Aboriginal and Torres Strait Islander participation in the Second World War. Drawing primarily on archival records, Hall traces how the Australian government initially excluded the enlistment of persons 'not substantially of European origin or descent' but overlooked such regulations after Pearl Harbor. Hall also discusses the role of those Indigenous activists hoping to achieve citizenship rights through military service and the role of Indigenous labour in the remote north. ${ }^{17}$ Hall followed up in 1995 with Fighters from the Fringe, examining the Second World War stories of six servicemen and women. ${ }^{18}$ Whereas The Black Diggers relies on non-Indigenous sources, Fighters from the Fringe provides Aboriginal and Torres Strait Islander perspectives about the Second World War and how military service impacted upon their lives. These 'positive' stories constructed an enduring dominant narrative about the military representing a site of opportunity for Aboriginal and Torres Strait Islander Australians.

\section{Reconciliation and National Narratives}

Aside from Hall's work and one other 1991 monograph compiling brief veterans' life stories, ${ }^{19}$ during the 1990s there was little historical research on Aboriginal and Torres Strait Islander military service. Whereas in other countries the reconciliation agendas generated interest in Indigenous military histories, in Australia public and academic histories still focused on past atrocities to contextualise present disadvantage. The so-called History Wars of 1996 to 2007, coinciding with the conservative Prime Ministership of John Howard, pitted

\footnotetext{
${ }^{16}$ Huggonson, 'The Dark Diggers of the AIF', 352-357.

${ }^{17}$ Hall, The Black Diggers.

${ }^{18}$ Hall, Fighters from the Fringe.

${ }^{19}$ Jackomos and Fowell, Forgotten Heroes.
} 
historians of Indigenous Australia against a political agenda that sought to downplay or even deny frontier massacres and the Stolen Generations. ${ }^{20}$ Writing new histories of Aboriginal and Torres Strait Islander people in the armed forces was not on most historians’ agendas.

In contrast, Native American military service finally received scholarly attention in the United States. Three monographs - by Alison Bernstein (1991), Jeré Bishop Franco (1999) and Kenneth Townsend (2000) - focus on the Second World War and are similar in scope and argument. ${ }^{21}$ They examine the legal and social status of Native Americans in the 1930s before tracing the impact of the war itself. All scholars consider the multiple complex reasons that Native Americans enlisted, ranging from warrior traditions to economic hardship to patriotism. Native American nations overwhelmingly supported the war effort, and many saw it as an opportunity both to assert their sovereign rights and to argue for full equality in the United States. Native American service personnel, integrated in units with whites, generally found the war to be egalitarian. The end of the war ushered in the beginnings of a pan-Native American movement, but at the same time their military service had been so successful that it 'proved' to the government that Native Americans were 'ready' to assimilate, presaging termination and relocation policies in the 1950s.

The 1990s also witnessed the first monographs on Native American participation in other twentieth-century conflicts. Based heavily on oral history interviews, Tom Holm's monograph Strong Hearts, Wounded Souls (1996) has been influential for its balanced focus on the war, martial race theory and veteran experiences. He gives strong credence to Native American agency and also emphasises the continuing importance of military service in Native American communities. ${ }^{22}$ Thomas Britten added the First World War to Native American historiography in 1997. His book examines similar issues to the Second World War

\footnotetext{
${ }^{20}$ See Macintyre and Clark, The History Wars.

${ }^{21}$ Bernstein, American Indians and World War II, Franco, Crossing the Pond, Townsend, World War II and the American Indian.

${ }^{22}$ Holm, Strong Hearts, Wounded Souls.
} 
studies: government approaches to Native American service, motivations to serve, the valorous experiences on the Western Front, the homefront and the quashed hopes for equal rights. Britten, too, emphasises Native American agency, particularly through the use of recorded oral history testimonies, and he also pays attention to how stereotypes and martial race ideas influenced Native American assignments in the armed forces. ${ }^{23}$ Holm and Britten’s texts, in conjunction with the aforementioned Second World War texts, set a clear dominant narrative of twentieth-century Native American military history.

Unlike in the other nations, in New Zealand there has always been a popular memory of Māori military service built around the Second World War 28 ${ }^{\text {th }}$ (Māori) Battalion (commonly known simply as the Māori Battalion). The Māori Battalion was formed in October 1939 and, unlike the First World War Pioneer Battalion, was a regular infantry force. Almost 3,600 Māori served in the Battalion, seeing action in Greece, Crete, North Africa and Italy. There was an official commissioned history published in 1956 and re-published in 2011. ${ }^{24}$ The Māori community frequently celebrates the achievements of the Battalion and it is continuously a part of New Zealand's military commemorations. Perhaps the popular prominence of the Battalion is one reason why it has actually received little academic attention. Wira Gardiner published the first popular monograph narrating the Battalion's history in $1995 .{ }^{25}$ Although there have not been academic monographs, the Māori Battalion features in numerous interactive websites which also include photographs, Battalion diaries and veterans' testimonies. ${ }^{26}$

While the significance of the Māori Battalion to Māori identity - and indeed to all of New Zealand's national identity - cannot be emphasised enough, this focus on the Māori Battalion overshadows the history of approximately 12,400 other Māori who served in

\footnotetext{
${ }^{23}$ Britten, American Indians in World War I.

${ }^{24}$ Coady, 28 (Maori) Battalion.

${ }^{25}$ Gardiner, Te Mura o Te Ahi.

${ }^{26}$ See $28^{\text {th }}$ Maori Battalion, http://www.28maoribattalion.org.nz/.
} 
integrated units in the Second World War, including Māori women in the nursing corps. There has also been no scholarly work on Māori service in the Korean or Vietnam Wars, even though Māori were a significant proportion of New Zealand's forces. Therefore, while there is a strong understanding of the importance of military service as a contemporary manifestation of Māori warrior traditions, there are still significant gaps in the scholarship.

Canada was late to tell the story of Native Americans in twentieth-century conflicts. Similar to South Africa, this was partly a symptom of the prominence of Native American participation in eighteenth and nineteenth-century home conflicts such as the French and Indian War (1754-1763) and War of 1812 (1812-1814). In 1989, James W. St.G. Walker examined Canadian Indians in the wider context of other racial minorities, including Chinese, Japanese and Blacks, arguing that desires to preserve the Canadian Expeditionary Force as a white institution overrode Canadians' pre-Confederation custom of recruiting Canadian Indian soldiers. Authorities only extended enlistment and conscription to Native Americans when labour shortages necessitated it. ${ }^{27}$ The first monograph about was James Dempsey’s Warriors of the King (1999). While he touched on all aspects of the Canadian Indian war experience including motivations to serve, combat, the homefront and disempowered veterans, the book's brevity leaves it an introduction to the topic. ${ }^{28}$

The first decade of the twenty-first century finally witnessed the rise of a Canadian First Peoples military historiography, intentionally distinct from that of Native Americans in the United States. R. Scott Sheffield's 2004 monograph The Red Man's on the Warpath used constructs of Canadian Native Americans as a prism through which to tell their Second World War history. Sheffield argues that both the 'administrative' and 'public' Indian constructs - often indicative of the martial race - were highly adaptive to suit war needs, but

\footnotetext{
${ }^{27}$ Walker, 'Race and Recruitment in World War I', 1-26.

${ }^{28}$ Dempsey, Warriors of the King.
} 
that fundamentally racial concepts of European superiority continued to dominate both the public and administrative perceptions of Native Americans. ${ }^{29}$

Hence by the twenty-first century, there was an existing historiography in all Anglosettler societies. In all countries except South Africa there were even similar dominant narratives: notwithstanding years of government oppression, Indigenous people enlisted in times of war hoping for improved civil rights and economic opportunities. Once they were in the forces, they were treated as equals, but they returned home to continuing discrimination. As veterans, though, their experience working alongside white (wo)men empowered them to fight for civil rights.

\section{Diversifying Histories}

The new century saw historians expanding these narratives - not challenging the historiography so much as emphasising the diversity of soldier experiences. In the United States, this meant looking at Code Talkers as not just a Navajo phenomenon. William C. Meadows' The Comanche Code Talkers (2002) examines the history of Code Talkers across all Native American nations in both the First and Second World Wars (albeit focusing on the Comanches). It is through the prism of Code Talkers that he tells the history of Native American military service in both wars, building on the themes explored in the works of Bernstein, Franco, Townsend and Britten. ${ }^{30}$

P. Whitney Lackenbauer's Battle Grounds (2007) takes the history of Canadian First Peoples and the military in a new direction by focusing on the relationships between Aboriginal Canadian communities and the Canadian military over bases. Through case studies across the twentieth century, Lackenbauer demonstrates the tensions between defence needs and First Peoples' land rights. Charting the twentieth century shows how the military-

\footnotetext{
${ }^{29}$ Sheffield, The Red Man's on the Warpath.

${ }^{30}$ Meadows, The Comanche Code Talkers of World War II.
} 
First Peoples relationships have reflected the contemporaneous Canadian-First Peoples relationships in civilian life. ${ }^{31}$ Also telling the history of Canadian First Peoples and the military across Canadian history is a volume co-edited by Lackenbauer and Craig Leslie Mantle (2007). It includes chapters focusing on as early as the colonial wars, but also on the two world wars, veterans' lack of recognition, the role of Second World War servicewomen and the post-war defence of remote northern Canada. ${ }^{32}$

Second World War and Vietnam War veterans have also published autobiographies in the United States in the 1990s and early 2000s. ${ }^{33}$ Other firsthand accounts were published in collections of oral histories, including: Native American First World War testimonies collected immediately after the war and later edited by Susan Krouse (2007); J. Boyd Morningstorm's (2004) life stories of veterans across the twentieth century; and Grace Poulin's (2007) under-cited work with Second World War Canadian Aboriginal servicewomen. Poulin's testimonies demonstrate the education and skills training that Canadian Aboriginal women obtained in the women's auxiliaries, which were relatively free from racism. ${ }^{34}$ What makes the firsthand accounts distinct is both the ways the authors position themselves within the dominant narratives of Indigenous war service, as well as how they emphasise the personal impacts of the war and the ways military service empowered them to take leadership roles in Indigenous communities.

Several Canadian and American texts narrate veterans’ memories through a mixture of fiction and autobiography, reflecting genres of Indigenous writing. ${ }^{35}$ In Australia, too, Kenny Laughton’s memoir Not Quite Men, No Longer Boys (1999) represents a fictionalised

\footnotetext{
${ }^{31}$ Lackenbauer, Battle Grounds.

${ }^{32}$ Lackenbauer and Mantle (eds), Aboriginal Peoples and the Canadian Military.

${ }^{33}$ MacDonald, The Last Warrior; TeCube, Year in Nam; Kipp, Viet Cong at Wounded Knee; Northrup, The Rez Road Follies; Stabler, No One Ever Asked Me.

${ }^{34}$ Krouse, North American Indians in the Great War, Poulin, Invisible Women, MorningStorm, The American Indian Warrior Today.

${ }^{35}$ St Pierre, Of Uncommon Birth; Cummings, Moon Dash Warrior; Red Eagle, Red Earth.
} 
autobiographical account of his Vietnam War service. ${ }^{36}$ In the United States, Indigenous soldiers or veterans are common characters in Native American fiction, including the works of prominent authors such as Louise Erdrich, Sherman Alexie and Michael Dorris. ${ }^{37}$ Canadian Anishinaabe author Joseph Boyden’s critically acclaimed novel Three Day Road (2005) follows the experience of an American Indian in the First World War, based on the real life of Pegahmagabow. ${ }^{38}$ Māori author Patricia Grace’s novel Tu (2004) is the first to focus on the Māori Battalion during the Second World War. She draws on her father and uncles' experiences to depict the horrors of war and the difficulty both veterans and families experienced coping with trauma. ${ }^{39}$ Māori author Witi Ihimaera's 2000 novel The Uncle's Story crosses genres by telling the story of a Māori soldier who falls in love with an American pilot in Vietnam. The novel not only addresses the importance of military service traditions in contemporary Māori families, but also the challenges confronting gay, lesbian and bisexual Māori. ${ }^{40}$ Fiction writers have been more effective than the autobiographical or historical accounts at demonstrating the reverberations of war service across families and communities. Post-traumatic stress disorder (PTSD) and the related problems of substance abuse and family violence are themes which these authors explore but which historians (except for Tom Holm and myself) have not yet addressed.

\section{From the National to the Transnational to the Colonial}

In the last few years the new historiography is again shifting primarily in two directions: examination of specialised Indigenous units and, coinciding with wider historiographical trends, the rise of comparative and transnational Indigenous military histories. In New

\footnotetext{
${ }^{36}$ Laughton, Not Quite Men, No Longer Boys.

${ }^{37}$ See, for instance, Erdrich, Love Medicine; Alexie, War Dances; Dorris, A Yellow Raft in Blue Water. See also Hundt, 'The warrior in the memoirs and fiction of Native American Vietnam War literature'.

${ }^{38}$ Boyden, Three Day Road. See also Hayes, Pegahmagabow.

${ }^{39}$ Grace, $T u$.

${ }^{40}$ Ihimaera, The Uncle's Story.
} 
Zealand this has manifested through closer, more detailed publications about the Māori Battalions in both the First and Second World Wars. Leading this charge is Māori historian Monty Soutar, who produced a 447-page encyclopaedic history of the Second World War $28^{\text {th }}$ (Māori) Battalion, ${ }^{41}$ and is currently completing a similar volume on the First World War Māori Pioneer Battalion. In Canada, Lackenbauer's The Canadian Rangers (2013) examines the past and present defence of remote regions through the Canadian Rangers program. Though not exclusively Indigenous, the Canadian Rangers employ a large number of Inuit and Native Americans. Lackenbauer uses a mix of oral histories and documentary research to show not only the effectiveness of the ranger program, but also how it has benefited Inuit communities through skills training and engendering community pride. ${ }^{42}$ Lackenbauer, with Sheffield and Mantle, also edited the first book to bring together scholars from across the Anglo-settler colonies researching various twentieth-century Indigenous military histories. ${ }^{43}$

Combining a focus on specialised Indigenous units with the new transnationalism, my own monograph Defending Whose Country? (2012) compares the roles of Yolngu Aboriginal people, Papua New Guineans and Navajo Code Talkers in the Second World War. I argue that while for Indigenous servicemen the war was an opportunity to work as allies with settler governments, from the government/military perspectives the utilisation of Indigenous skills for the war effort did not represent respect for Indigenous culture or agency. ${ }^{44}$ Posing a similar argument in the First World War context is Timothy Winegard's Indigenous People of the British Dominions and the First World War (2012). Winegard is the first historian to analyse Indigenous Australians, Canadians, New Zealanders and South Africans in a transnational context. He comprehensively outlines how all four countries adapted their approaches to Indigenous military service both to meet the needs of the British war effort,

\footnotetext{
${ }^{41}$ Soutar, Nga tama toa $=$ The Price of Citizenship.

${ }^{42}$ Lackenbauer, The Canadian Rangers.

${ }^{43}$ Lackenbauer et. al (eds), Aboriginal Peoples and Military Participation.

${ }^{44}$ Riseman, Defending Whose Country?.
} 
while concurrently asserting their own distinct policies to preserve their nations' racial ideologies. ${ }^{45}$ David Killingray (2010) has also recontextualised South Africa's Second World War history in the transnational British Africa context. By including South Africa alongside British colonial policies, Killingray highlights both the distinctive policies of South Africa while demonstrating the common racial ideologies at play across British Africa. ${ }^{46}$

Contemporary scholars such as myself and Winegard are also paying more attention to the problematic martial race epithet across the various settler societies and conflicts. This, too, is part of wider historiographical trend examining the history of European racial discourse, and we are applying that historical discourse to the armed forces. Native American activist Winona LaDuke’s The Militarization of Indian Country (2013) traces the long history of US military discourses and martial race stereotypes of Native Americans to argue their detrimental impact on Native American communities. She is cautious not to disrespect those men and women who have served - just as other historians have been careful - but still produces an effective (albeit polemical) critique of the historical and ongoing relationship between the United States military and Native American communities. ${ }^{47}$

Winegard also recently produced a defining monograph on Canadian Indian First World War history. For King and Kanata (2012) traces both Canadian Indian motivations to serve, as well as government policies evolving from exclusion, to tacit acceptance, to targeting Native Americans and ultimately conscription. ${ }^{48} \mathrm{I}$ am the first scholar to write about Aboriginal and Torres Strait Islander service after the Second World War, including in the Vietnam War and in the women's services. ${ }^{49} \mathrm{I}$ am also part of a large Australian Research Council-funded study entitled 'Serving Our Country', being led by prominent Aboriginal Professor Mick Dodson. Partnered with the Department of Veterans' Affairs, Department of

\footnotetext{
${ }^{45}$ Winegard, Indigenous Peoples of the British Dominions and the First World War.

${ }^{46}$ Killingray, Fighting for Britain.

${ }^{47}$ LaDuke, The Militarization of Indian Country.

${ }^{48}$ Winegard, For King and Kanata.

${ }^{49}$ Riseman, 'Equality in the Ranks', 411-426; Riseman, 'Escaping Assimilation’s Grasp’ (forthcoming).
} 
Defence, Australian War Memorial and National Archives of Australia, the project will produce a comprehensive history of Aboriginal and Torres Strait Islander military service from the Anglo-Boer War until the present.

\section{Conclusion: Commemorating Indigenous Service}

The issue of commemorating Indigenous service looms large across the settler societies. Indigenous veterans' groups have existed in the United States since at least the 1970s and in Canada since at least the early 1980s; in Australia they began to form in the early 2000s. These groups regularly organise services, ceremonies such as Pow-wows, and have lobbied for memorials and medals to recognise Indigenous service. In Australia there are now even a few memorials to Indigenous service, most prominently in Adelaide and Sydney. ${ }^{50}$

The majority of historians writing about Indigenous military service are not Indigenous. ${ }^{51}$ This poses the questions of whose histories we are writing, and do we have the authority to write such histories. These are debates about Indigenous history in general, with various scholars posing different viewpoints. What is striking, though, is that among Indigenous ex-service communities, there has been little resistance to non-Indigenous historians conducting this research. Based on my own experience, what is most important to Indigenous ex-service personnel and their families is that these long-forgotten histories be shared and commemorated. There are of course important ethical and cultural protocols to observe; the researcher must build trust with Indigenous communities (particularly when conducting oral history interviews) and the texts should allow Indigenous voices to be heard. But fundamentally, most of the texts discussed in this article, particularly since the 2000s,

\footnotetext{
${ }^{50}$ On Canberra's memorial, see Brennan, 'Lest We Forget', 34-44.

${ }^{51}$ The exceptions are Native American scholars Tom Holm and Winona LaDuke and Māori scholar Monty Soutar. Timothy Winegard has Iroquois heritage as well. Aboriginal Professors Mick Dodson and John Maynard are Chief Investigators on a current project historicising Aboriginal and Torres Strait Islander military service from the Boer War until the present.
} 
have emerged through cooperative partnerships between non-Indigenous researchers and Indigenous participants.

One major question historians and commemorations are now confronting is how to situate frontier wars as part of a long history of Indigenous military service. New Zealand regularly includes the mid-nineteenth-century New Zealand Wars as part of its long military history. So too, to a much lesser extent, do the United States and Canada acknowledge the frontier wars and the roles played by Native Americans both in settler armies and resisting colonialism. In post-apartheid South Africa, frontier wars form part of a longer history of Black resistance against white oppression. In Australia, while military historians have regularly described the frontier wars as part of Australia's military history, ${ }^{52}$ they are not commemorated as such in the Australian War Memorial or Anzac Day celebrations. Prominent historian Henry Reynolds' recent book Forgotten War (2013) questions the absence of the frontier wars from Australia's public commemorations of war. ${ }^{53}$ While I agree with Reynolds that frontier conflicts should indeed be recognised as wars, I disagree with his implication that commemorations of Indigenous participation in the Australian armed forces is at the expense of commemorating the frontier wars. Even so, the challenge that Reynolds poses to the Australian nation to remember the frontier wars signals a possible new direction in the historiography of Indigenous military service.

\footnotetext{
${ }^{52}$ See Connor, The Australian Frontier Wars, 1788-1838; Grey, A Military History of Australia.

${ }^{53}$ Reynolds, Forgotten War.
} 


\section{Bibliography}

$28^{\text {th }}$ Māori Battalion, http://www.28Māoribattalion.org.nz/, accessed 28 August 2014.

Adair, J. and Vogt, E. 'Navaho and Zuni Veterans: A Study of Contrasting Modes of Culture Change’, American Anthropologist 51/4, part 1 (October-December 1949): 547-561. Alexie, S. War Dances. (New York: Grove Press, 2009).

Bernstein, A. R., American Indians and World War II: Toward a New Era in Indian Affairs. (Norman, OK: University of Oklahoma Press, 1991).

Bixler, M.T. Winds of Freedom: The Story of the Navajo Code Talkers of World War II. (Darien, CT: Two Bytes Publishing Company, 1992).

Boyden, J. Three Day Road. (New York: Viking, 2005).

Brennan, A. 'Let We Forget: Military Myths, Memory, and Canberra’s Aboriginal and Torres Strait Islander Memorial', Memory Connection 1/1 (2011): 34-44.

Britten, T. A. American Indians in World War I: At Home and at War. (Albuquerque, NM: University of New Mexico Press, 1997).

Brokaw, T. The Greatest Generation. (New York: Random House, 1998).

Clothier, N. Black Valour: the South African Native Labour Contingent, 1916-1918, and the Sinking of the Mendi. (Pietermaritzburg: University of Natal Press, 1987).

Coady, J.F. 28 (Māori) Battalion. (Wellington: New Zealand Department of Internal Affairs. War History Branch, 1956; republished 2012).

Connor, J. The Australian Frontier Wars, 1788-1838. (Sydney: UNSW Press, 2002).

Cowan, J. The Māoris in the Great War: A History of The New Zealand Native Contingent and Pioneer Battalion. (Auckland: Whitcombe \& Tombs Limited, 1926).

Cummings, D. Moon Dash Warrior: The Story of an American Indian in Vietnam, a Marine from the Land of the Lumbee. (Livermore, ME: Signal Tree Pub., 1998). 
Dempsey, J.L. Warriors of the King: Prairie Indians in World War 1. (Regina, SK: Canadian Plains Research Center, University of Regina, 1999).

Dorris, M. A Yellow Raft in Blue Water. (New York: Henry Holt \& Co, 1987).

Durrett, D. Unsung Heroes of World War II: The Story of the Navajo Code Talkers. (New York: Facts on File, Inc, 1998);

Erdrich, L. Love Medicine. (originally published 1984; republished New York: HarperCollins, 2005).

Evans, J., Grimshaw, P., Philips, D. and Swain, S. Equal Subjects, Unequal Rights: Indigenous Peoples in British Settler Colonies. (Manchester: Manchester University Press, 2003).

Franco, J. B. Crossing the Pond: The Native American Effort in World War II. (Denton, TX: University of North Texas Press, 1999).

Gardiner, W. Te Mura o Te Ahi: The Story of the Mãori Battalion. (Auckland: Reed, 1995).

Grace, P. Tu. (Honolulu: University of Hawai`i Press, 2004).

Grey, J. A Military History of Australia, 3rd ed. (Cambridge: Cambridge University Press, 2008).

Grundlingh, A. Fighting Their Own War: South African Blacks and the First World War. (Johannesburg: Ravan Press, 1987).

—. 'The King's Afrikaners? Enlistment and Ethnic Identity in The Union of South Africa's Defence Force During the Second World War, 1939-45', The Journal of African History 40/3 (1999): 351-365.

Grundy, K. Soldiers Without Politics: Blacks in the South Africa Armed Forces. (Berkeley and Los Angeles: University of California Press, 1983).

Hall, R. The Black Diggers: Aborigines and Torres Strait Islanders in the Second World War. (Sydney: Allen \& Unwin, 1989). 
—. Fighters from the Fringe: Aborigines and Torres Strait Islanders Recall the Second World War. (Canberra: Aboriginal Studies Press, 1995).

Hayes, A. Pegahmagabow: Legendary Warrior, Forgotten Hero. (Sault Ste. Marie: Fox Meadow Creations, 2006).

Hayes, G., Iarocci, A. and Bechthold, M. Vimy Ridge: A Canadian Reassessment. (Waterloo, ON: Wilfred Laurier University Press, 2007).

Holm, T. Strong Hearts, Wounded Souls: Native American Veterans of the Vietnam War. (Austin, TX: University of Texas Press, 1996).

Huggonson, D. 'The Dark Diggers of the AIF', The Australian Quarterly 61/3 (spring 1989): 352-357.

Hundt, S. 'The warrior in the memoirs and fiction of Native American Vietnam War literature’, PhD diss. (Lehigh University, 2006).

Ihimaera, W. The Uncle’s Story. (Auckland: Penguin Books, 2000).

Jackomos, A. and Fowell, D. Forgotten Heroes: Aborigines at War, from the Somme to Vietnam. (South Melbourne: Victoria Press, 1993).

Johnson, B.H. (ed.). Navajos and World War II. (Tsaile, AZ: Navajo Community College Press, 1977).

Killingray, D. Fighting for Britain: African Soldiers in the Second World War. (Woodbridge, UK: Boydell \& Brewer Ltd, 2010).

Kipp, W. Viet Cong at Wounded Knee: The Trail of a Blackfeet Activist. (Lincoln: University of Nebraska Press, 2004).

Krouse, S. A. North American Indians in the Great War. (Lincoln, NE: University of Nebraska Press, 2007).

Lackenbauer, P.W. Battle Grounds: The Canadian Military and Aboriginal Lands. (Vancouver: UBC Press, 2007). 
—. The Canadian Rangers: A Living History. (Vancouver: UBC Press, 2013).

Lackenbauer, P.W. and Mantle, C.L. (eds). Aboriginal Peoples and the Canadian Military:

Historical Perspectives. (Kingston, ON: Canadian Defence Academy Press, 2007).

Lackenbauer, P.W., Sheffield, R.S. and Mantle, C.L. (eds). Aboriginal Peoples and Military Participation: Canadian and International Perspectives. (Kingston, ON: Canadian Defence Academy Press, 2007).

LaDuke, W. The Militarization of Indian Country. (East Lansing, MI: Makwa Enewed, Michigan State University Press, 2013).

Lake, M. and Reynolds, H. What's Wrong with Anzac? The Militarisation of Australian History. (Sydney: UNSW Press, 2010).

Laughton, K. Not Quite Men, No Longer Boys. (Alice Springs, NT: IAD Press, 1999).

MacDonald P. with Ted Schwarz. The Last Warrior: Peter MacDonald and the Navajo Nation. (New York: Orion Books, 1993).

Macintyre, S. and Clark, A. The History Wars. (Carlton, VIC: Melbourne University Press, 2003).

McClain, S. Navajo Weapon: The Navajo Code Talkers. (Tucson, AZ: Rio Nuevo Publishers, 2001).

Meadows, W.C. The Comanche Code Talkers of World War II. (Austin: University of Texas Press, 2002).

MorningStorm, J. B. The American Indian Warrior Today: Native Americans in Modern U.S. Warfare. (Manhattan, KS: Sunflower University Press, 2004).

Northrup, J. The Rez Road Follies: Canoes, Casinos, Computers, and Birch Bark Baskets. (Minneapolis: University of Minnesota Press, 1999).

O’Connor, P.S. ‘The Recruitment of Māori Soldiers, 1914-18’, Political Science 19 (1967): 48-83. 
Paul, D.A. The Navajo Code Talkers. (Philadelphia: Dorrance \& Company, 1973)

Poulin, G. Invisible Women: WWII Aboriginal Servicewomen in Canada. (Thunder Bay, ON: D.G. Poulin, 2007).

Pugsley, C. Te Hokowhitu a Tu: The Māori Pioneer Battalion in the First World War. (Auckland: Reed Books, 1995).

Red Eagle, P. Red Earth: A Vietnam Warrior’s Journey. (Duluth, MN: Holy Cow! Press, 1997).

Reynolds, H. Forgotten War. (Sydney: NewSouth Publishing, 2013).

Riseman, N. Defending Whose Country? Indigenous Soldiers in the Pacific War. (Lincoln: University of Nebraska Press, 2012).

—. 'Equality in the Ranks: The Lives of Aboriginal Vietnam Veterans', Journal of Australian Studies 36/4 (December 2012): 411-426.

—. 'Escaping Assimilation’s Grasp: Aboriginal Women in the Australian Women’s Military Services', Women's History Review (forthcoming).

Scates, B., et. al. ‘Anzac Day at Home and Abroad: Towards a History of Australia’s National Day’, History Compass 10/7 (2012): 523-536.

Sheffield, R.S. The Red Man's on the Warpath: The Image of the "Indian" and the Second World War. (Vancouver: UBC Press, 2004).

Soutar, M. Nga tama toa = The Price of Citizenship: C Company 28 (Māori) Battalion 19391945. (Auckland: David Bateman, 2008).

Stabler, H. No One Ever Asked Me: The World War II Memoirs of an Omaha Indian Soldier, ed. V. Smith. (Lincoln: University of Nebraska Press, 2005).

St Pierre, M. Of Uncommon Birth: Dakota Sons in Vietnam. (Norman, OK: University of Oklahoma Press, 2003). 
TeCube, L. Year in Nam: A Native American's Story. (Lincoln: University of Nebraska Press, 1999).

Townsend, K. W. World War II and the American Indian. (Albuquerque, NM: University of New Mexico Press, 2000).

Vogt, E. Navaho Veterans: A Study of Changing Values. (Cambridge, MA: Peabody Museum of Harvard University, 1951).

Walker, J.W. St.G. 'Race and Recruitment in World War I: Enlistment of Visible Minorities in the Canadian Expeditionary Force’, Canadian Historical Review 70/1 (1989): 1-26.

Winegard, T.C. For King and Kanata: Canadian Indians and the First World War.

(Winnipeg: University of Manitoba Press, 2012).

Indigenous Peoples of the British Dominions and the First World War. (New York: Cambridge University Press, 2012). 